\title{
Bird Stories from Latin America: Lessons on Change and Adaptation
}

\author{
Nicole Sault ${ }^{1^{*}}$ \\ ${ }^{1}$ Sally Glean Center, Palo Alto, USA. \\ *nicole@sallyglean.org
}

\begin{abstract}
When people hear bird sounds, they understand them on various levels that are interpreted according to cultural context. Among Indigenous cultures of Latin America, avian voices are understood in relation to group identity, kinship affiliation, and personal experience, such as dreams and vision quests. Birds are recognized as social actors with their own voices that express intentions, desires, needs, and responsibilities. Certain birds may impart messages to specific people, and stories of these personal interactions represent both traditional values as well as individual explanations for what the bird communicated. These experiences are incorporated into the dynamic relationships people have with birds, the ancestors, the landscape, and spirit beings, and assist in addressing both cultural and climatic changes. This essay presents stories from Mexico, Costa Rica, and Peru, and shows how individuals interpret bird communications according to cultural values that relate to their personal situation. These avian messages gain new meaning and urgency during periods of dramatic change, like the current climate crisis. As people seek creative responses to survive, relationships with birds provide resiliency.
\end{abstract}

Resumen Cuando las personas escuchan los sonidos de las aves, los entienden por varios niveles que se interpretan de acuerdo con el contexto cultural. Entre las culturas indígenas de América Latina, las voces de las aves se entienden en relación con la identidad grupal, la afiliación de parentesco y la experiencia personal, como los sueños y las búsquedas de una visión. Las aves son reconocidas como actores sociales con sus propias voces que expresan intenciones, deseos, necesidades y responsabilidades. Ciertas aves imparten mensajes a personas específicas, y las historias de estas interacciones personales representan tanto valores tradicionales como interpretaciones particulares de lo que el ave les comunicó. Tales experiencias personales se incorporan a las relaciones dinámicas que las personas tienen con las aves, los antepasados, el paisaje, y los seres espirituales. Estas experiencias también se relacionan con cambios culturales y climáticos. Este ensayo presenta historias de México, Costa Rica y Perú, que muestran cómo las personas interpretan las comunicaciones de las aves de acuerdo con los valores culturales que se relacionan con su situación personal. Estos mensajes de las aves adquieren un nuevo significado y urgencia durante los periodos de cambios dramáticos, como la actual crisis climática. A medida que las personas buscan respuestas creativas para sobrevivir, las relaciones con las aves proporcionan resiliencia.

Received April 1, 2020

OPEN ठACCESS

Accepted July 17, 2020

DOI 10.14237/ebl.11.2.2020.1689

Published December 4, 2020

Keywords Indigenous peoples, Oral tradition, Climate crisis, Mexico, Costa Rica, Peru

Copyright (c) 2020 by the author(s) licensee Society of Ethnobiology. This is an open-access article distributed under the terms of the Creative Commons Attribution-NonCommercial 4.0 International Public License (https://creativecommons.org/licenses/by-nc/4.0), which permits non-commercial use, distribution, and reproduction in any medium, provided the original author and source are credited.

\section{Introduction}

The sounds birds make include calls and songs, but there are other ways that birds are heard beyond physical utterances and fluttering feathers. Human societies from nations to clans recognize birds for their special powers. Some groups claim particular bird species as their representatives, hoping to draw upon avian powers. Certain species are associated with either war or peace, the heavens or the underworld, while others are connected with geographical features of the land or specific spirits and deities. These relationships are exemplified in flags, shields, coins, totems, headdresses, and jewelry, as well as songs, dances, and stories.

Much has been written about bird communication in various forms and contexts, usually in the sense of the meanings attributed to the 
appearance or behavior of particular bird species, such as eagles, hummingbirds, doves, or owls. Yet, research has shown that the meanings conveyed by the appearance and behavior of bird species vary from one culture to another, and can be interpreted in contrasting ways depending on details of the birds' behavior and the personal history of the observer (Forth et al. 2010; Hull and Fergus 2017; Hunn 2008).

Within a particular culture, avian-human relationships have enduring meanings that are transmitted over generations because they resonate with a group's history and values. Meanwhile, individual human experiences continue to enter oral traditions and writings. When human-avian interactions are narrated to others, the newer stories are heard in reference to past meanings that resonate to recent events, individual encounters, and changing circumstances. New stories of personal experiences build on their antecedents and continue to teach succeeding generations about heeding bird messages that instruct, advise, warn, and guide. Rather than a boundary separating traditional stories from more recent ones, there is a continuous flow of meaning that enriches both, for time is recognized as cyclical and round. Stories of recent origin gain validity from previous narratives, which in turn are recalled as relevant to contemporary life, as illustrated here by examples from the Zapotec of Mexico, the Bribri of Costa Rica, and Quechua-speaking peoples of Peru. These three stories show how birds are still heeded as messengers, harbingers, advisors, teachers, and protectors. As the Zapotec poet Irma Pineda affirms, "our stories will be reborn/ you will not see me die" (Sullivan 2012:45).

\section{Methods}

While my research in Latin America began decades earlier, the focus on ethno-ornithology began in 2002, while I was teaching at the University of Costa Rica and visiting Bribri communities. Methods were mainly qualitative and included literature reviews, consultations with local scholars and authorities, visits to museums, photographs, walks with bird guides, participant observation in daily activities and ceremonies, extended interviews, and group discussions. I presented my work in Spanish at conferences in Costa Rica and Peru and read early versions of manuscripts to the people I worked with in order to consult with them.

Permission from local authorities and consultants was obtained whenever possible. For the first story by
Pedro Chávez Garcia, who is from a Valley Zapotec village, when I asked permission to publish his story he agreed and asked that his full name be used. The second story is from Ana Balma, a Bribri woman from the Talamanca region of southeastern Costa Rica. She shared her stories with me and has also published stories in an edited volume (Bozzoli et al. 1982). The third story was published previously by the author, Cronwell Jara Jiménez, of Piura in northern Peru, but the background to the story is based on interviews I conducted with him. He is delighted to have his work recognized and thanked me for acknowledging what he and his wife are doing to encourage storytelling and recover traditional stories.

I sought out stories that depict how people relate to birds in reference to cultural traditions and the contemporary context. These three stories were selected because they illustrate how bird meanings are significant for people's lives and guide their responses to current issues, whether natural disasters related to climate change or socio-cultural changes they are adapting to and/or resisting. The three stories embody ongoing truths that are maintained through oral tradition and still relevant today, addressing a sense of urgency for discerning how to proceed when faced with uncertainty. The stories are exemplars of a larger corpus that provides a context for interpreting personal experience and broader societal events. While the experience of a particular bird's behavior may be unique, these avian narrations and commentaries show how the three authors perceive each story within a larger context that amplifies their meaning and guides the narrator's response, as well as influencing family and friends. The past guides us in the present and illumines the future.

\section{A Fabric of Feathers}

In Latin America, birds are woven into the fabric of life. Feathers are used in weavings, shields, headdresses, wands, rattles, and prayer offerings (Espejo Ayca 2015; Filloy Nadal 2019; Giuntini 2006). At the national level birds are represented in flags, such as the eagle on the cactus of the Mexican flag. At the local level birds are honored and celebrated, expressing totemic relationships to ancestors belonging to descent groups like clans or as members of extended kin networks.

People are also connected to particular birds through personal experience. Sometimes people seek 


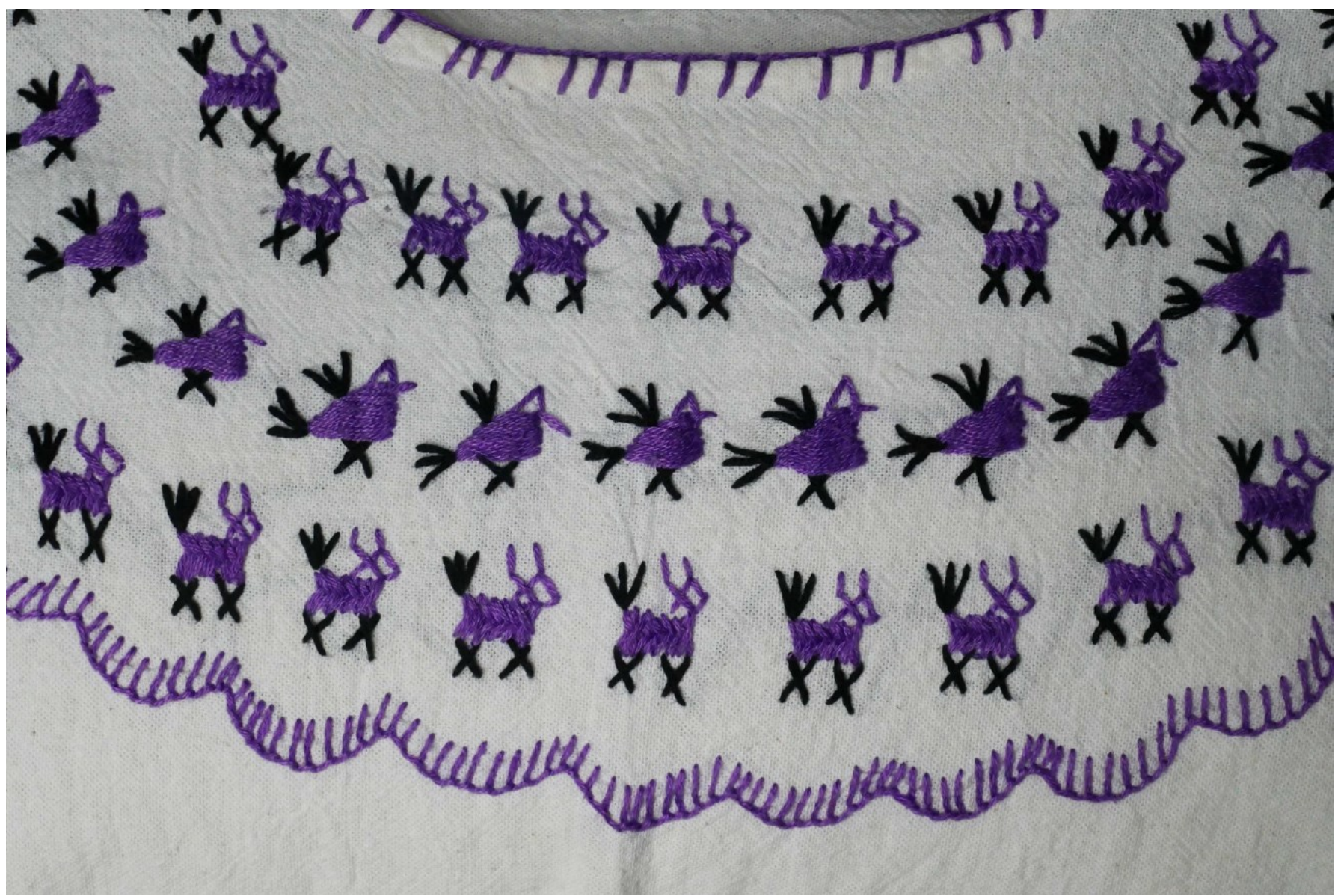

Figure 1 Huipil blouse with bird and animal design. Tacuate, Mixteca. Oaxaca, Mexico 2018.

out certain kinds of birds for their spiritual meaning, to learn a song or chant, and for guidance in assessing an undertaking or journey. Less documented or understood are the relationships established when birds appear to an individual to advise or teach something.

Such a relationship with a bird may be limited to one occasion that is fleeting or become ongoing, as will be described below. Even if the relationship between bird and human is not reenacted beyond the initial event, the relationship may be relived and perpetuated in the stories of the family that enter into the memory of oral tradition as the descendants retell what occurred.

When birds are recognized for their spiritual significance, the powers they embody can imbue a family with a sense of the bird's ongoing presence and protection or assistance. The sound of these birds' voices reverberates along channels of inter-species communication beyond the limits of human hearing, for these voices are apprehended at a deep level that connects ancestors with their descendants and with the spirit beings of forests, mountains, and waters.

\section{Bird Wisdom among the Zapotec of Mexico}

The ancient Zapotec civilization honored birds in many forms, such as in the Post-Classic stone register celebrating the marriage of Lady Qualaala Xopa, which depicts birds carrying jewels in their beaks to represent the sacred knowledge of the ancestor guardians who have "elite knowledge that was vital to the society's well-being" (Flores-Marcia 2015:95). The significance of birds continues in songs, omens, poetry, and stories (Sault 2016). The Zapotec poet Antonio López Pérez refers to his language as a bird "that runs/ in the mountains/ walks upon the feet/ of children, old people" (Sullivan 2012:45).

My research among Zapotec of the Oaxaca Valley in southeastern Mexico provided various accounts of birds that have significance in both positive and negative ways. For example, the Vermilion flycatcher (Pyrocephalus rubinus) —or, in local Spanish, venturilla- 
means good luck when the male flycatcher shows his day-glow scarlet breast. However, when he shows his black back this is inauspicious. Another auspicious bird people often pointed out is the Great Kiskadee (Pitangus sulphuratus) or pecho amarillo (yellow breast). When the bird's yellow breast is shown this means good luck (buena suerte). In asking people about birds, I was interested in the general meanings for the community, but also individual variation among villagers, as shown by their personal accounts of bird encounters.

One story stood out in particular, about a small yellow bird the storyteller called El Pájaro Cartero (The Bird Letter Carrier). As agency is attributed to birds and this one is referred to by the speaker as "he," I am translating the reference to the bird as "who" rather than "it." The same attribution of agency holds for birds in other regions. This story is about faith in the wisdom of a particular bird and was told to me by Pedro Chávez Garcia. (We could not identify exactly which species of bird this was). Pedro said:

When I was ten years old, in 1962, my grandfather pointed out to me a small yellow bird that hopped about in a tree and called out, drawing attention. My grandfather explained to me that the bird came to announce that a letter for him had arrived. You see, my aunt and the other relatives in Mexico City would write to my grandfather and send the letters to a furniture store in Oaxaca City, where my grandfather would go to pick them up. There were no telephones then, but the little bird told him whenever a letter arrived, hopping in the tree by the house and singing. Each time the bird visited my grandfather, he would go into the city and there would be a letter waiting for him.

Pedro's commentary on the story was: "La naturaleza avisa pero no ponemos atención." (Nature tells us, but we don't pay attention. Translation mine.) He noted that all around us there are signs and messages, but often we ignore them, especially nowadays. Pedro's grandfather could not read the letters or write one himself, and there were no telephones. Yet by understanding that birds can be messengers, he knew how to "read" the bird's message, just as others knew how to "read" the moon and the clouds for predicting the weather and earthquakes.
For this Zapotec family, the story of the Bird Letter Carrier reinforces the belief that if you attend to the world around you and trust in the wisdom of birds-what they are trying to teach you - then you will be rewarded. While the story is unique to this family, their belief in the bird's powers grows out of an older and broader understanding of other beings having power for both good and bad. This contemporary story echoes past events and demonstrates key values that are reinforced with each narration. The story also illustrates the variation in bird meanings that are dynamic and resilient, adapting to changed conditions through particular meanings that still connect with older traditions.

\section{Generosity and Reciprocity in Costa Rica}

The Bribri represent the largest Indigenous group in Costa Rica today, with a long and rich history in the Talamanca region of the southeast. Their respect for birds is reflected in avian images of gold or stone and ancient ceramic pieces. Bribri leaders wore headdresses with bird feathers and necklaces with images of birds made of gold (Fernández and Sánchez 2009). The power of birds continues to be expressed in chants, dances, medicine, clan names, paintings, and stories (Bonatti 2003; Guevara 2004; Sánchez 1996-1997; Sault 2016). Many people told me stories about birds who can be helpful or harmful, as depicted in the sacred stories of traditional myths or related regarding contemporary events. The stories, songs, and dances show how birds like parrots, hummingbirds, and vultures can advise, protect, or even rescue people.

Some stories depict how a person is assisted by a bird in a special way. For example, the Bribri say that turkey vultures (Cathartes aura) can help orphans and honorable people by providing food. Ana Balma told me her own particular experience of this, which her sons and other relatives corroborated. She said when you are planting seeds in the forest, if turkey vultures fly over or rest in the trees, you can call out to them for help.

One day when she was planting corn and beans in a cleared patch of the forest, turkey vultures flew over. As an orphan, she asked the vultures to have pity on her. She called to them and sang: "Usted está viajando, usted trae semilla, usted me da su semilla y yo le doy la mía." (You are traveling. You carry seeds. Give me some of your seeds, and I will give you some 


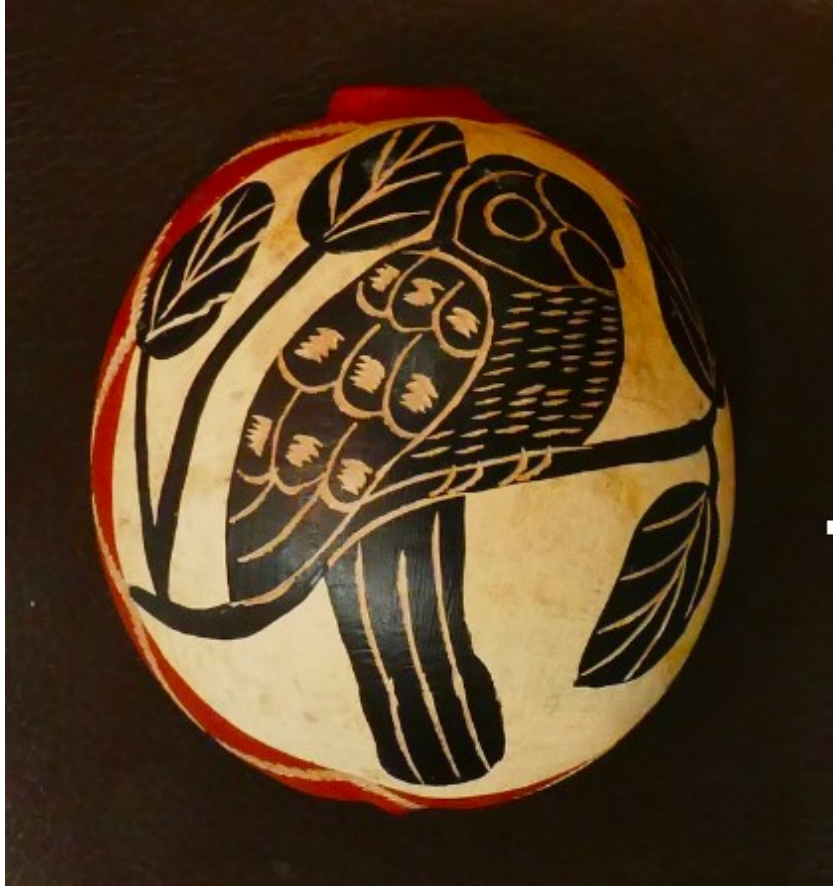

Figure 2 Bribri carved gourd with parrot, Talamanca, Costa Rica 2019.

of mine; author's translation). As Ana told me: "You do an exchange. You ask the turkey vulture, not other vultures, because the turkey vulture migrates and each being carries food along to eat-seeds and water for the journey to faraway places north" (interviewed February 28, 2007, author's translation).

Where she planted corn and beans, a month later squash plants appeared, though she had not planted any squash seeds. The squash grew strong and vigorous, giving the family much to eat. Her family said they knew the squash were a gift because no one had ever planted there before and Ana had sowed only corn and beans. These were the gifts of the turkey vultures to an orphan. Due to the current uncertainty in weather patterns, drought, and flooding, both wild and domestic plant foods are not as reliable as once before, so the help of vultures and other animals has greater urgency.

This story exemplifies Bribri beliefs about the sacred power of vultures, who performed key roles at the time of Creation and have healing powers (Palmer et al. 1992; Sánchez Pereira and Bozzoli Vargas 19971998). Ana's response to the gift of the turkey vultures is in keeping with Bribri beliefs and practices that recognize birds as beings with special knowledge and abilities with which Sibö (God) has endowed them
(Bonatti 2003; Fernández and Sánchez 2009; Guevara 2004; Sánchez Pereira and Bozzoli Vargas 1997-1998; Sault 2010). Her story is unusual for outsiders in that we do not associate vultures with seed-eating, but for the Bribri vultures are sacred teachers and protectors who are generous in their gifts of song, dance, and seeds. They are messengers or embodiments of Sibö (God), and their connection to seeds resonates with the Bribri, as their origin myths say the first people came from corn and the Bribri still think of themselves as precious kernels of corn.

Birds guide people in planting and gathering, hunting and fishing, or undertaking journeys. People attend to bird calls, migrations, and absences, for the changes induced by the global climate crisis have affected birds as well as people and plants. When Ana beseeched the vultures for help, she was acting upon long-held beliefs that birds and other animals can assist people who are honorable or hinder those who break taboos and otherwise flaunt social norms. She perceived her ability to communicate with the vultures within a larger context of birds as messengers, guides, helpers, healers, and guardians. A story that draws on older traditions guides people today in adapting to changing circumstances, such as unseasonal weather and flooding that affect homes and crops. While circumstances vary over time, the underlying values are maintained and reinforced. This exemplifies how traditions are dynamic, helping to sustain and encourage people in times of dramatic change and conflict.

Reclaiming Voices of Wisdom and Justice in Peru In Latin America, of the many birds recognized for their powers and abilities the majestic Andean Condor (Vultur gryphus) is especially honored as a being of great power and wisdom. In keeping with what Garibaldi and Turner (2004) call "cultural keystone species," the condor is what one could call a "cultural keystone bird" who represents the central values of many Andean cultures and is honored for their ability to mediate, protect, and teach.

Ornithologists describe condors as having no voice, making only hisses and grunts. However, in the Andes the condor is recognized as having a variety of different "voices." Condor feathers produce an airy sound as the birds rise on the thermals. There is also a long tradition of using the feather quills and bones of condors to make musical instruments that create a mournful sound. 
Condors are prominent in Andean songs, dances, dreams, and ceremonies, for they represent the spirits of mountain deities or Apus. Condors are the embodiment of these deities, sent as their messengers (Bastien 1985; Jara Jiménez 1990; Sánchez Garrafa 2005:68; Sault 2016). From the mountains of Machu Picchu to the coast of Paracas, condors are depicted in textiles, ceramics, carvings, astronomy, medicine, place names, kinship and politics (Gordillo 2000; Ibarra et al. 2012). Through condor rituals, relationships with the mountains are maintained in equilibrium (Sánchez Garrafa 2005:209). Ceremonies are performed for condors because they represent the sacred mountains that can either send rain clouds or detain them.

Condors have "voices" in many cultural formsvoices that are powerful for their dignity, wisdom, and authority. In some highland communities, the staff of office for a village official is decorated with a silver head of a male condor as the arbiter of justice.

The power of condors is recognized and honored not only throughout the Andean highlands but also along coastal areas, as condors travel back and forth between these two ecological zones. From their mountain nesting areas, they soar down to the coast to forage on the carcasses of sea mammals, birds, and fish, as well as the afterbirth from seals. People told me the condors also come to skim the foam off the waves, which represent the water that will return to the mountains through clouds and rain. People walk down from the altiplano highlands to the seashore, making pilgrimages to honor and celebrate this connection to the sea, where they gather seaweed and fish eggs to take back home for ritual meals. The condors are part of this watery cycle, as they fly back and forth from high to low through the clouds as harbingers of the precious rains, soaring before the storms that gather in the mountains.

Given this association of condors with the coastal areas as well as the mountains, it is not surprising that condors play an important role in the coastal region of northern Peru in places such as in Piura. Cronwell Jara Jiménez, from Piura, describes how the Condor is the totem of the clan condori (1990). He has written in detail about condors in this region, drawing upon the stories handed down by his grandmother, his mother, and a cousin who lived in the mountains above Piura during the 1920s and 1930s. As he told me, "I would listen to their stories and write them down. One day I decided to be a writer" (interview in Lima, Peru,

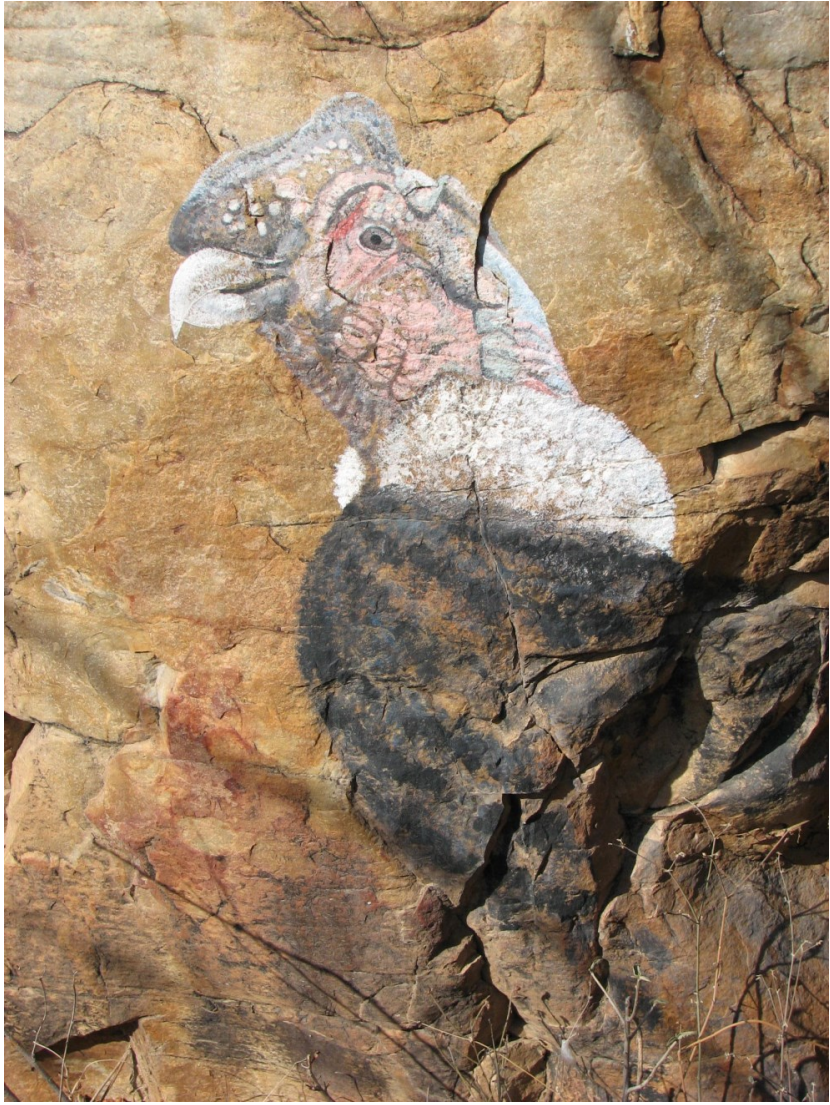

Figure 3 Contemporary rock painting of male Andean Condor (Vultur gryphus) in Chaparrí, Lambayeque, coastal Peru 2014.

December 29, 2013). He was twelve years old when he made this decision and was encouraged by his father.

He told me that in the past certain men with spiritual power were allowed to catch condors for ceremonies. The condor would then be carried through the streets on an anda (portable platform), and people made offerings of silver and images of tiny deer (interview in Lima, Peru, December 29, 2013). Jara Jiménez explained that in Piura there was a special group of men who were trained by the grandfathers for organizing and presiding over these condor ceremonies. The condor was later sacrificed (sacrificado) to remove the wing bones and make flutes. Some said that it was wrong to kill the condor, who is a divinity (una divinidad), and they released the condor after the procession through the streets. Then the condor would fly back to the mountains. Jara Jiménez said: Los apus, allí está la casa del espiritu de la divinidad, el condor (The mountain deities, there is the house of the spirit of the divinity, the condor; author's translation). 


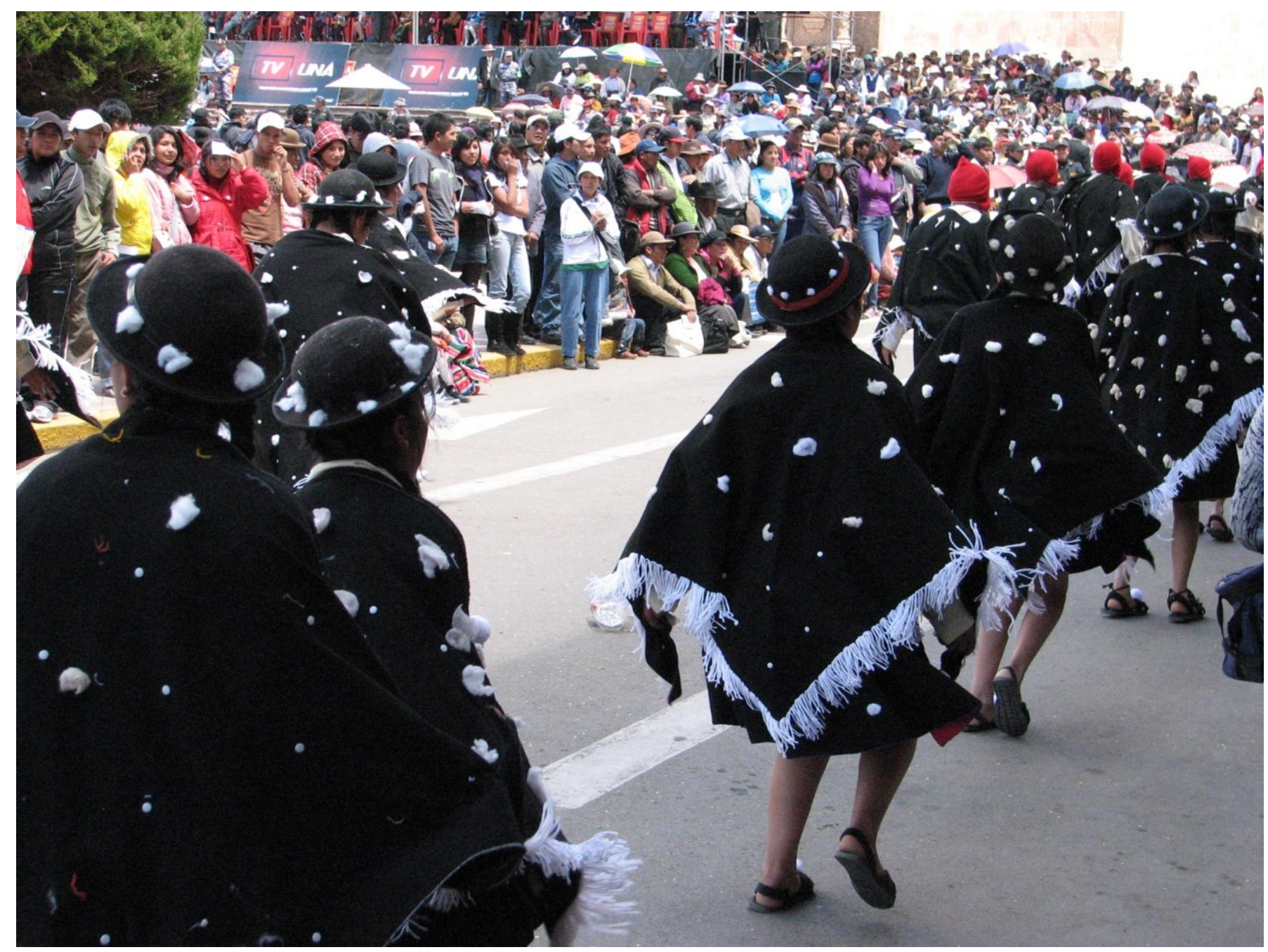

Figure 4 Condor dancers, Universidad Nacional del Altiplano (students from the National University of the Altiplano) in Puno, Peru, September 15, 2011. The women in black hats represent female condors and the men in red caps represent male condors.

Inspired by the stories from his early life in Piura, Jara Jiménez (1990) depicts the power of condors in his book, Don Rómulo Ramirez, Cazador de Cóndores (Don Romulo Ramires, Hunter of Condors; author's translation). The story revolves around the dilemma of a traditional condor hunter who is told to capture one for a ceremony, but decides that this would be wrong and refuses. He is incessantly pressured by the community to capture a condor, and what unfolds in the story is the drama around these conflicting forces and the condor's response.

With sadness, Jara Jiménez told me how people are forgetting the ceremonies and do not practice them anymore. The stories are not always passed down and are lost. This is why he and his wife, Cecilia
Granadino, feel called to gather the stories of the elders, record them in their original languages like Quechua, and publish them in these languages as well as in Spanish. The goal they have embraced is to recover and share these stories about condors, frogs, spiders, rain, and other personages, as in the book Stories of Our Quechua Grandparents: Recovering Oral Tradition (Granadino 1993, translation mine). In these stories the cultural values of respect, cooperation, and reciprocity are portrayed and re-valued.

While Jara Jiménez draws on the oral tradition within his community to present the stories and develop dramatis personae, he both honors the cultural values and explores the tensions that modern life presents in the Andes. People on the street stop 
him to express how the power of his writing has affected them because they say it represents Peruvian reality. Meanwhile, he and Granadino are using the written word to record and recover the oral traditions of other regions, with the permission and blessing of the spiritual leaders. They exemplify the ways in which oral and literate traditions can enrich and sustain each other.

\section{First Voices and Silences}

People still share sacred stories of the Creationwhen birds appeared before humans. Many cultures explain that people first learned to talk from birds, and that birds are the intermediaries with the deities. Back then people and birds could transform into one another, and humans could still understand the language of birds (March 1898:209). Among the ancient cultures of Mexico, it was the custom for people to live with birds, especially ones thought to be capable of human speech (Aguilera 2001, cited in Guirao-Cruz et al. 2014:108).

There are some who continue to communicate with birds and share bird talk stories. Bird talk is recognized on many levels-interpreted for prognosticating weather or death and disease, bearing messages, witnessing solemn occasions, or auguring good luck and well-being (Wyndham et al. 2018). For the Embera of Panama (Kane 2015:35), bird songs and calls

are located between the invisible and the human worlds as they inform people of new birth and impending death. Because songs and calls depart and are distinct from the avian bodies that produce them, they can travel across the space of the imagination as well as physical space.

Bird talk is not unidirectional from birds to people, as people also talk to birds in various ways. As individuals people communicate with birds on a oneto-one basis, and in groups community members address birds in ritual contexts officiated by local leaders. For example, in the Andes it is generally recognized that people talk to condors, hawks, and many other birds through words, songs, dances, and ceremonies (Bastien 1985; Granadino 1993). In Sicily they say that certain people can talk to crows and are privy to their secrets, believing that crows "communicate the latest news on the doings of human beings since they have a clear view - a bird'seye view, in fact—of the whole" (Camilleri 2007:129).
Stories encode the wisdom of birds as to how the world is construed and teach people the ways of right living. Stories also connect people with place, reaffirm their connection to the ancestors, and represent spiritual relationships that define their cultural identity (O’Brien Lyver and Moller 2010:242). But as Tideman et al. (2010:5) have noted:

Too often, ethno-ornithological knowledge is reported from the perspective of an outsider and therefore appears to be in some way devalued. The terms legends, fables, tales, myths and stories are frequently used for indigenous knowledge, but not always in a way that engenders respect or an understanding of the place of birds in cultures.

Yet the power of stories cannot be overestimated. For many Indigenous peoples of North America, "Renewal ceremonies, the telling and retelling of creation stories, the singing and resinging of the songs, are all humans' part in the maintenance of creation" (Little Bear 2019:2). Among the Mãori of New Zealand, oral narrative reinforces the power of the ancestors "to discipline those who do not uphold the correct practices" (O'Brien Lyver and Moller 2010:253). This relationship with birds and other beings involves the practice of what the Mãori call kaitiakitanga or environmental guardianship (2010:242, 246). In southeastern Mexico, the Zoque of Tapalapa, Chiapas, say that the quetzals (Pharomachrus mocinno) are their protectors and companions who provide them with blessings and keep away evil spirits (Guirao -Cruz et al. 2014:112, 115). These cultures emphasize mutual responsibility with birds and other beings, including the land.

Birds communicate through calls, songs, feather vibrations, and tapping patterns. They also communicate through silences. Bird silences can indicate danger, disapprobation, and loss. Silence can also mean the absence of birds, and people interpret this as an indication of the state of the land. For the Zoque of Mexico, the call of the quetzal is related to the sound of the trees (Aguilera 2001, cited in GuiraoCruz et al. 2014:111). The absence of the sounds of quetzals means that the health of the forest has been harmed (2014:113).

Around the world the sounds of birds are disappearing, and human beings are a major factorby killing birds, destroying their habitat, and failing to honor them and perform ceremonies. Since 1970 there are nearly three billion fewer birds in North 
America (Lambert 2019). A key factor is the global climate crisis, about which scientists recognize birds as important indicators.

Worldwide, birds are respected for their ability to warn of such disasters. Among the Ikoot (Huave) of San Mateo del Mar in Oaxaca, Mexico, calls of birds announce changes in the climate. Such birds include the Double-striped Thick-Knee (B. bistriatus) known locally as the Alcaravan or Berelele and the calandrias (Icterus spp.) (Cruz Jacinto et.al. 2014:160). In Peru the indicators of global climate change, disasters and flooding are swallows, known as vencejos, golondrinas, or Santa Rosita (Sotíl Galindo 2008:99). Peruvian biologist Gilmar Vergara explained to me that violeteared hummingbirds (Colibri coluscans) announce the arrival of the rainy season. But he has noted disturbing alterations in their behavior, with delays in their arrival and their songs sung out of season. He observes that "there will be no rain. Everything is altered by the phenomenon of climate change" (Vergara, interviewed on October 20, 2015 in Cusco, Peru).

In 1962, Rachel Carson warned us of The Silent Spring. What happens when avian voices are suppressed, like the voices of Indigenous peoples in the Americas? What are the consequences of knowing birds only through books or videos? What is altered when bird stories are no longer told and shared? At the United Nations climate summit, Mãori representative from the Indigenous Peoples Organizations, Kera Sherwood-O'Regan (Goodman 2019), spoke to the need for hearing stories that have long been ignored:

When you silence us, you deny yourselves learning from our ways, and you continue to sideline those who have real solutions for all communities. We are experts on climate. We are the kaitiaki, the stewards of nature. We know the legitimacy of our voices, and it's about time that you recognized it, too. Hear our stories. Learn our histories. Stop taking up space with your false solutions and get out of our way.

Birds communicate through both sound and silence, by their presence and by their absence. When birds are understood as an integral part of creation, people recognize that there are consequences for failing to heed these voices and silences.

Birds are generous, giving us gifts of beauty, sustenance, and wisdom. The role of birds in bearing omens and warnings has long been recognized, and in these times of dramatic climate crisis their messages and teachings carry even greater urgency. Rather than ignoring avian voices and Indigenous teachings that have been handed down over generations, may we listen to what the birds are trying to tell us through their voices, their silences, and the stories.

\section{Acknowledgements}

In gratitude to the original peoples of Latin America, in particular the Zapotec, Bribri, and Quechuaspeaking peoples, who shared their knowledge and wisdom with great generosity and patience. In particular I want to thank María Eugenia Bozzoli, Orlando Bedoye, and Peter Reynolds. Thanks also to the organizers of the annual meetings of the Society for Ethnobiology, held in Vancouver, British Columbia, Canada in 2019. An earlier version of this material was presented at a session I organized for the meetings there on "Avian Voices in Song, Story, Wisdom, and Warning." All photographs were taken by the author.

\section{Declarations}

Permissions: Permissions obtained.

Sources of funding: None declared.

Conflicts of Interest: None declared.

\section{References Cited}

Bastien, J. W. 1985. Qollahuaya-Andean Body Concepts: A Topographical-Hydraulic Model of Physiology. American Anthropologist 87:595-611.

Bonatti, J. G. 2003. El Zopilote: Caquero y Psicopompo. II Congreso Sobre Pueblos Indígenas. Universidad de Costa Rica, San José, Costa Rica.

Camilleri, A. 2007. The Patience of the Spider: An Inspector Montalbano Mystery. S. Sartarelli, trans. Penguin, New York, NY. Originally Published in Italian, Pazienza del Ragno. 2004. Sellerio Editore, Palermo, Italy.

Bozzoli Vargas, M., C. Cubero Venegas, M. Sánchez Perreira, A. Calderón Saravia, and J. Segundo Sánchez. 1982. Tradición Oral Indígena Costarricense, Relatos Bribris de Kekoldi, Provincia de Limón. Volumen IV, Año IC, Número 1-2. Universidad de Costa Rica, San José, Costa Rica.

Cruz Jacinto, M. A., M. A. Vásquez-Dávila, P. Colunga García-Marín, and M. P. Jerez Salas. 2014. Aspectos Etnoecológicos de la Ornitofauna Entre los Ikoot de San Mateo del Mar, Oaxaca, México. In Aves, Personas y Culturas. Estudios de Etno-ornitología 1, 
edited by M. A. Vásquez-Dávila, pp. 151-167. CONACYT/ITVO/Carteles Editores/UTCH, Oaxaca, México.

Fernández, P. E., and J. Sánchez. 2009. Aves de Piedra, Barro y Oro en la Costa Rica Precolombinal Birds of Stone, Clay and Gold in pre-Columbian Costa Rica. Fundación Museos del Banco Central, San José, Costa Rica.

Filloy Nadal, L. 2019. De la Pluma y Sus Usos en Mesoamérica. Arqueología Mexicana 159:18-23.

Flores-Marcia, X. M. 2015. A History of Guelaguetza in Zapotec Communities of the Central Valleys of Oaxaca, 16 th Century to the Present. Doctoral Dissertation, University of California, Los Angeles, California. Available at: https://escholarship.org/ content/qt7tv1p1rr/qt7tv1p1rr.pdf. Accessed on April 24, 2020.

Garibaldi, A., and N. Turner. 2004. Cultural Keystone Species: Implications for Ecological Conservation and Restoration. Ecology and Society 9:1. DOI:10.5751/es-00669-090301.

Giuntini, C. 2006. Precolumbian and Ethnographic Featherwork from the Andes and Amazon in the Metropolitan Museum of Art. Nuevo Mundo Mundos Nuevos 1457. DOI:10.4000/nuevomundo.1457.

Goodman, A. 2019. COP25 Was a Failure, But Activists' Collective Organizing at the Talks Was Unprecedented. Democracy Now. [web page]. A vailable at: ht t p s : / / www.democracynow.org/2019/12/16/ cop25_failure_asad_rehman_tasneem_essop. Accessed on December 16, 2019.

Granadino, C., ed. 1993. Cuentos de Nuestros Abuelos Quechuas: Recuperando La Tradición Oral (Stories of Our Quechua Grandparents: Recovering Oral Tradition (my translation). WASAPAY, Lima, Perú.

Guevara Berger, M. 2004. Por una Epistemología Nuestra: Política y Antropología, Desde los Bribris. Anales de Antropología 38:201-228. DOI:10.22201/ iia.24486221e.2004.1.16590.

Guirao-Cruz, R. E., L. Gamay, and S. L. ArriagaWeiss. 2014. Aproximación a la Cosmovisión y al Conocimiento Zoque Sobre el Quetzal (Pharomachrus mocinno) en Tapalapa, Chiapas, México. In Aves, Personas y Culturas. Estudios de Etno-ornitología 1, edited by M. A. Vásquez-Dávila, pp. 107-117. CONACYT/ ITVO/Carteles
Editores/UTCH, Oaxaca, México.

Hull, K., and R. Fergus. 2017. Birds as Seers: An Ethno-Ornithological Approach to Omens and Prognostication Among the Ch'Orti' Maya of Guatemala. Joumal of Ethnobiology 37:604-620. DOI:10.2993/0278-0771-37.4.604.

Jara Jiménez, C. 1990. Don Rómulo Ramirez, Cazador de Cóndores (Don Romulo Ramirez, Hunter of Condors). CIPCA: Centro de Investigacion y promocion del Campesinado, Serie: Cuentos Piuranos no. 5, Miraflores, Peru.

Kane, S. 2015. Bird Names and Folklore from the Emberá (Chocó) in Darién, Panamá. Ethnobiology Letters 6:32-62. DOI:10.14237/ebl.6.1.2015.226.

Lambert, J. 2019. We've Lost 3 Billion Birds Since 1970 in North America. Science News. Available at: https://www.sciencenews.org/article/3-billionbirds-lost-since-1970-north-america. Published on September 19, 2019.

Little Bear, L. 2019. Jagged Worldviews Colliding. Walking Together: First Nations, Métis and Inuit Perspectives in Curriculum. Government of Alberta, Edmonton, Canada. Available at: http:// www.learnalberta.ca/content/aswt/worldviews/ documents/jagged_worldviews_colliding.pdf. Accessed on July 16, 2020.

March, C. 1898. The Mythology of Wise Birds. Journal of the Anthropological Institute of Great Britain and Ireland 27:209-232.

O'Brien Lyver, P., and H. Moller. 2010. An Alternative Reality: Maori Spiritual Guardianship of New Zealand's Native Birds. In Ethno-ornithology: Birds, Indigenous Peoples, Culture and Society, edited by S. Tideman and A. Gosler, pp. 241-264. Earthscan Ltd., London, England.

Palmer, P., J. Sánchez, and G. Mayorga. 1992. Vias de extinción, Vias de supervivencia: Testimonios del Pueblo Indígena de la Reserva KéköLdi, Costa Rica. Editorial de la Universidad de Costa Rica, San José, Costa Rica.

Sánchez, J. 1996-1997. Relatos Bribris de Kekoldi, Provincia de Limón, Costa Rica. Tradición Oral Indigena Costarricense 4:1-83.

Sánchez Garrafa, R. 2005. Apus de los Cuatro Suyos: Construcción del Mundo en los Ciclos Mitológicos de las Deidades Montaña. Doctoral Dissertation, Department of Anthropology, Universidad 
Nacional Mayor de San Marcos, Lima, Peru. Available at: http://cybertesis.unmsm.edu.pe/ handle/cybertesis/2749. Accessed on June 15, 2016.

Sánchez Pereira, M., and M. E. Bozzoli Vargas. 19971998. Motivos Faunísticos en la Cultura Indígena Costarricense. Estudios de Lingüística Chibcha: Tomo 16:113-144.

Sault, N. 2010. Bird Messengers for All Seasons: Landscapes of Knowledge among the Bribri of Costa Rica. In Ethno-ornithology: Peoples, Culture and Society, edited by S. Tidemann and A. Gosler, pp. 291-300. Earthscan Ltd, London, England.

Sault, N. 2016. How Hummingbird and Vulture Mediate Between Life and Death In Latin America. Journal of Ethnobiology 36:783-806. DOI:10.2993/0278-0771-36.4.783.

Sotíl Galindo, R. 2008. Iconografia de la Cultura Nasca. Lima, Perú. Universidad Alas Peruanas. Available at: http://www.jstor.org/stable/2641288. Accessed on May 6, 2017.
Sullivan, C. 2012. The State of Zapotec Poetry: Can Poetry Save an Endangered Culture? World Literature Today. Available at: https:// www.worldliteraturetoday.org/2012/january/statezapotec-poetry-can-poetry-save-endangered-culture. Accessed on September 22, 2019.

Tideman, S., S. Chirgwin, and J. R. Sinclair. 2010. Indigenous Knowledges, Birds that Have 'Spoken' and Science. In Ethno-ornithology: Birds, Indigenous Peoples, Culture and Society, edited by S. Tideman and A. Gosler, pp. 3-12. Earthscan, London, England.

Wyndham, F., K. Park, and J. Fanshawe. 2018. "Listen Carefully to the Voices of the Birds": A Comparative Review of Birds as Signs. Journal of Ethnobiology 38:535-549. DOI:10.2993/0278-077138.4.533. 